QUALITY

Volume 8, Nomor 2, 2020, 207-218

\title{
Implementasi Metode Yanbu'a untuk Meningkatkan Hasil Belajar Baca Al-Quran di MI Baitul Huda Kota Semarang Tahun Ajaran 2019/2020
}

\author{
Mohammad Rofiq \\ UIN Walisongo Semarang, Semarang, Indonesia \\ mrofiq@walisongo.ac.id \\ Muhammad Abdul Basyid \\ IAIN Kudus, Kudus, Indonesia \\ abdulbasyid@gmail.com
}

\begin{abstract}
Abstrak
Implementasi Metode Yanbu'a Untuk Meningkatkan Hasil Belajar Baca Al-Quran Di Mi Baitul Huda Kota Semarang Tahun Ajaran 2019/2020. Penelitian ini bertujuan untuk mengetahui pelaksanaan pembelajaran Alquran menggunakan metode Yanbu'a di MI Baitul Huda semarang. Jenis penelitian ini adalah penelitian kualitatif deskriptif. Teknik pengumpulan data dilakukan dengan wawancara dan dokumentasi. Analisis data yang digunakan mengikuti analisis model miles dan huberman yaitu reduksi data, penyajian data dan verifikasi. Hasil penelitian ini menunjukan bahwa: pertama penerapan metode Yanbu'a di MI Baitul Huda dilakukan dengan beberapa metode yang berbasis pembalajaran aktif, inovetif, kreatif, efektif, dan menyenangkan. kedua peran metode yanbu'a dalam pembelajaran baca Al-quran di MI Baitul Huda sangat penting dalam meningkatkan hasil belajar baca Al-Qur'an. Berdasarkan hasil penelitian menunjukkan bahwa metode ini mampu meningkatkan kemampuan siswa dalam baca Al-qur'an sesuai dengan makharijul huruf dan tajwid.
\end{abstract}

Kata Kunci: Metode Yanbu'a, Hasil Belajar, MI Baitul Huda

\begin{abstract}
Implementation of the Yanbu'a Method to Improve Learning Outcomes of Reading Al-Quran at Mi Baitul Huda Semarang City for the 2019/2020 Academic Year. This study aims to determine the implementation of AlQuran learning using the Yanbu'a method at MI Baitul Huda Semarang. This type of research is descriptive qualitative research. The data collection technique is done by interview and documentation. The data analysis used follows the Miles and Huberman model analysis, namely data reduction, data presentation and verification. The results of this study indicate that: firstly, the application of the Yanbu'a method at MI
\end{abstract}


Baitul Huda was carried out with several methods based on active, innovative, creative, effective, and fun learning. The second role of the yanbu'a method in learning to read the Al-Quran at MI Baitul Huda is very important in improving learning outcomes to read Al-Qur'an. Based on the research results, it shows that this method is able to improve the students' ability to read Al-quran according to the makharijul letters and tajwid.

Keywords: Yanbu'a method, Learning outcomes, MI Baitul Huda

\section{A. Pendahuluan}

Situasi pendidikan saat ini sedang dihadapkan pada berbagai perubahan dalam bentuk aspek kehidupan yang ada di masyarakat. Hal ini dikarenakan oleh kemajuan ilmu pengetahuan dan teknologi yang pesat, serta dampak globalisasi yang terjadi didunia termasuk bangsa Indonesia (Marianti, 2016). Hal ini pun berimbas pada pendidikan keagamaan khususnya dalam pengajaran Al- Quran. Tidak sedikit guru al-Quran yang mengajarkan cara baca Al- Quran dengan salah, yang tidak sesuai dengan tajwid atau makhorijul huruf yang telah diajarkan oleh Rasulullah SAW (saifudin, 2017:2). Disamping hal itu, ada salah satu hambatan yang paling menonjol dalam pelaksanaan pendidikan baca Al- Quran yaitu dalam hal penggunaan metode pengajaran al-Quran. Hal ini menjadi sangat urgen untuk diteliti karena penerapan metode pengajaran al-Quran yang kurang tepat dapat mengakibatkan kesalahan fatal terhadap cara membaca al-Quran anak-anak yang akan terus terbawa hingga mereka dewasa. Metode mengajar merupakan sebuah teknik untuk menyampaikan bahan pelajaran kepada peserta didik, yang dimaksudkan agar peserta didik dapat menangkap pelajaran dengan mudah, efektif, dan dicerna dengan baik. Hal ini mengindikasikan bahwa pemilihan metode mengajar yang tepat khususnya dalam pengajaran al-Quran akan sangat mempengaruhi hasil belajar yang diinginkan dapat dicapai oleh peserta didik/santri.

Al Qur'an merupakan mukjizat Nabi Muhammad SAW yang diturunkan Allah SWT melalui perantara malaikat Jibril yang digunakan sebagai pedoman hidup bagi umat muslim. Al Qur'an diturunkan di Jazirah Arab, oleh karena itu bahasa yang digunakan adalah bahasa Arab. Hal ini mengharuskan umat muslim 
yang tidak berasal dari jazirah arab haruslah belajar agar mampu membaca dan mempelajarinya, seperti umat Islam yang ada di Indonesia. Islam mewajibkan umatnya untuk selalu membaca, mempelajari, dan mentadaburi Al Qur'an yang kemudian diterapkan dalam kehidupan sehari-hari. Hal tersebut sesuai dengan salah satu fungsi Al Qur'an yaitu sebagai petunjuk dan pedoman bagi umat Islam.

Mengajarkan perilaku keagamaan kepada anak-anak tidaklah mudah, dibutuhkan suatu keahlian dan manajemen serta kiat-kiat khusus dari para ustadz, supaya anak-anak benar-benar memahami, menghayati, dan memiliki perilaku keagamaan yang sesuai harapan (Rohmad, 2004: 206). Di sisi lain, permasalahan muncul dari orang dekat anak. Kebanyakan orang tua cenderung menyekolahkan anaknya di lembaga-lembaga formal saja, dengan harapan kelak kemudian hari anaknya bisa menjadi orang-orang yang pandai dan intelek, namun mereka lupa terhadap pendidikan agamanya, penanaman nilai-nilai keagamaan, kepribadian dan ketaqwaannya sangat sedikit mereka fikirkan, sehingga secara tidak sadar orang tua menjauhkan anak-anaknya dari pendidikan agamanya, sebab mereka menganggap pelajaran keagamaan tidak begitu penting. Bagi mereka yang terpenting adalah kepandaian yang mampu menghasilkan materi sebanyak-banyaknya. Setelah anak mulai menginjak bangku menengah pertama, biasanya sudah tidak lagi memperhatikan pendidikan agamanya.

Peneliti menjumpai banyak anak-anak dan remaja muslim yang belum mampu membaca al-Quran. Padahal mereka mengakui bahwa kitab suci al-Quran adalah kitab yang menjadi petunjuk dan pedoman hidup bagi dirinya. Anak-anak dan remaja muslim sekarang banyak disibukkan dengan aktifitas sekolah formalnya dan mengikuti kegiatan lainnya, sehingga banyak sekali anak-anak muslim lulusan menengah yang masih buta huruf terhadap al-Quran. Hal seperti ini adalah hal yang sangat memalukan bagi umat Islam, karena bagi umat Islam ini adalah persoalan mendasar yang harus segera diatasi. Menyikapi permasalahan tersebut, banyak upaya yang dilakukan guru dalam meningkatkan kualitas belajar membaca alQuran pada murid- muridnya. Hal ini dilakukan karena guru memegang peranan penting dalam kegiatan pembelajaran maupun pelatihan (Fatmawati, Setyowati, \& 
Utomo, 2018: 89). Upaya yang dilakukan guru yaitu dengan melakukan tindakan yang bertujuan atau bersifat untuk meningkatkan kualitas baca al-Quran pada murid-muridnya. Namun pada kenyataanya masih banyak juga keluhan pada setiap lembaga Taman Pendidikan al-Quran yang berkaitan dengan masalah prestasi membaca al-Quran pada murid-muridnya. Melihat hal tersebut, peneliti merasa tertarik untuk meneliti hal itu karena merupakan salah satu bentuk upaya untuk ikut serta menjaga dan memelihara keaslian al-Quran, baik dari segi tulisannya maupun bacaanya, serta upaya mendukung efektifitas dalam pengembangan kemampuan membaca al-Quran. Dalam penelitian ini Peneliti mengambil tempat yaitu Madrasah Ibtidaiyah "Baitul Huda" Kec. Ngaliyan Kota Semarang. Dari uraian diatas, maka penulis tertarik mengadakan penelitian dengan judul "Implementasi Metode Yanbu'a untuk meningkatkan hasil belajar baca Al-Quran di MI Baitul Huda Semarang Tahun 2019/2020.”

Tujuan penelitian ini adalah untuk mengetahui implementasi metode Yanbu'a dalam pembelajaran al-Quran di MI Baitul Huda Semarang Tahun 2019/2020 serta peran metode Yanbu'a dalam pembelajaran al-Quran di MI Baitul Huda Semarang 2019/2020. Setelah mengetahui implmentasi metode Yanbu'a dan peran metode tersebut maka diharapkan mampu memberikan gambaran kepada para pembaca tentang implementasi metode Yanbu'a dalam proses pembelajaran Baca Al-Qur'an di lembaga pendidikan keagamaan.

Yanbu'a merupakan metode pembelajaran al-Quran ciptaan dari tim penyusun yang dipimpin oleh KH. M. Ulil Albab Arwani, beliau adalah putera kyai kharismatik dari Kudus yang dikenal sebagai ahli ilmu al- Quran yaitu KH. Muhammad Arwani. Metode Yanbu'a mempunyai arti sumber, mengambil dari kata Yanbū'ul Qur'an yang berarti sumber al- Quran. yanbu'a berkembang pada tahun 2004, terdiri dari 7 juz atau jilid untuk TPQ dan 1 juz untuk pra TK dan dalam pembelajarannya dimulai dengan pengenalan hurūf hijaiyyah beserta harakatnya ditulis secara bertahap, dari tingkat yang sederhana sampai kepada tingkat yang paling sulit. Selain itu, dalam yanbu'a tidak hanya diajarkan tentang membaca al- Qur'an saja, tetapi juga diajarkan menulis al-Quran (Arwani, 2004: 1). 
Munculnya Yanbu'a merupakan atas masukan dan dorongan dari alumni Pondok Tahfiz Yanbūee ul Quran, agar mereka selalu ada hubungan dengan pondok disamping pendapat dari masyarakat luas juga dari Lembaga Pendidikan Ma'arif serta Muslimat terutama dari cabang Kudus dan Jepara. Seharusnya dari pihak pondok sudah menolak, karena beranggapan bahwa sudah cukup dengan metode yang sudah ada. Namun karena adanya desakan yang terus menerus dan memang dipandang perlu, terutama untuk menjalin silaturrahmi antara alumni dengan pondok pesantren serta untuk menjaga dan memelihara keseragaman bacaan alQuran.

Penyampaian materi pembelajaran dengan metode Yanbu'a dilakukan dengan berbagai macam metode, antara lain: Musyāfahah yaitu guru membaca terlebih dahulu kemudian siswa menirukan. Melalui cara ini guru bisa menerapkan membaca huruf dengan benar melalui lidahnya. Sedangkan siswa akan dapat melihat dan menyaksikan langsung praktek keluarnya huruf dari lidah guru untuk ditirukannya.'Arḍ ul Qirā'ah yaitu siswa membaca di depan guru sedangkan guru menyimaknya. Sering juga cara ini disebut dengan sorogan. Pengulangan yaitu guru mengulang-ulang bacaan, sedangkan siswa menirukannya kata per kata atau kalimat per kalimat, juga secara berulang-ulang hingga terampil dan benar (Arwani, 2004: 2)

Penelitian ini terfokus pada penerapan metode Yanbu'a dalam pembelajaran membaca Al-Quran Siswa di MI Baitul Huda. Untuk mengungkap substansi penelitian ini diperlukan pengamatan yang mendalam dan dengan latar belakang yang alami. Dengan demikian pendekatan yang diambil adalah pendekatan kualitatif deskriptif (Lexy, 2002: 4). Pendekatan kualitatif merupakan penelitian untuk menyajikan dunia sosial dan perspektifnya dari segi konsep, perilaku, persepsi, serta persoalan tentang manusia (Fatmawati, 2020: 33). Penelitian mengambil lokasi di lembaga MI Baitul Huda Kecamatan Ngaliyan, Kota Semarang.

Teknik pengumpulan data menggunakan wawancara, observasi, dan studi dokumen. Analisis data dalam penelitian ini dilakukan melalui 3 (tiga) tahap, yaitu: 
pertama, reduksi data merupakan merangkum, memilih hal-hal yang pokok, memfokuskan pada hal-hal yang penting untuk dicari tema dan polanya. Dengan demikian data yang telah direduksi akan memberikan gambaran yang lebih jelas, dan mempermudah peneliti untuk melakukan pengumpulan data selanjutnya, dan mencarinya bila diperlukan. Hasil yang direduksi adalah hasil nilai membaca AlQur'an individu (sorogan) ketika penelitian berlangsung, dengan tujuan untuk mengetahui pencapaian kompetensi santri dalam membaca Al-Qur'an sesuai kompetensi dari metode yanbu'a. Kedua, penyajian data, dilakukan dalam bentuk tabel, grafik, pie shart, pictogram dan sejenisnya. Melalui penyajian data tersebut, maka data terorganisasikan, tersusun dalam pola hubungan, sehingga akan semakin mudah dipahami. Data-data yang disajikan berupa observasi, wawancara, dokumentasi, nilai/hasil belajar siswa, serta catatan lapangan yang dilakukan di MI Baitul Huda.

Langkah ketiga dalam analisis data adalah penarikan kesimpulan dan verifikasi. Kesimpulan awal yang dikemukakan masih bersifat sementara, dan akan berubah bila ditemukan bukti-bukti yang kuat yang mendukung pada tahap pengumpulan data berikutnya. Tetapi apabila kesimpulan yang dikemukakan pada tahap awal, didukung oleh bukti-bukti yang valid dan konsisten saat peneliti kembali ke lapangan mengumpulkan data, maka kesimpulan yang dikemukakan merupakan kesimpulan yang kredibel. Oleh karena itu dalam tahap ini akan dilakukan kegiatan verifikasi, yaitu menguji kebenaran, kekokohan, dan kecocokan makna-makna yang muncul dari data yang telah direduksi dan disajikan di atas.

\section{B. Pembahasan}

\section{Penerapan Metode Yanbu'a dalam Pembelajaran Al-Quran di MI Baitul Huda Semarang Tahun 2019-2020}

Penerapan metode yanbu'a dalam pembelajaran al-quran di MI Baitul Huda telah dilakukan sejak awal semester ini hingga sekarang. Dalam pelaksanaannya sehari-hari, ustadz-ustadzah tidak mengalami kesulitan yang berarti karena metode 
ini mudah diterapkan. Terdapat banyak petunjuk bagaimana penerapan metode ini di kelas, khususnya dalam pembelajaran al-quran.

Penerapan metode yanbu'a dalam pembelajaran al-quran di Mi Baitul Huda merupakan salah satu bentuk langkah nyata ikut serta dalam menjaga dan memelihara keaslian al-quran, baik dari segi tulisan maupun bacaannya, serta mendukung efektifitas dalam pengembangan kemampuan membaca al-quran. Adapun temuan penelitian terkait penerapan metode yanbu'a di MI Baitul Huda adalah sebagai berikut: Setiap ustadz-ustadzah pengampu jilid/juz masing-masing datang 5 menit lebih awal sebelum para santri untuk mengkondisikan kelas. Hal ini sangat menguntungkan karena ketika santri datang ada yang menyambut dan ketika pembelajaran berlangsung kelas dalam kondisi bersih untuk digunakan. Peserta didik yang datang selalu bersalaman dan mencium tangan ustdaz- ustadzahnya, kemudian mendapat pelukan dari ustadz yang diberikan kepada santriwan, ustadzah memeluk santriwati. Pada kegiatan klasikal, ustadz/ustadzah membimbing santrinya dengan sistem drill yakni contohkan-tirukan. Santri dengan serentak menjawab dengan suara keras. Jumlah peserta didik di MI Baitul Huda cukup banyak. Satu kelas jilid yang idealnya berisi maksimal 15 orang, bisa menampung 20 orang lebih. Hal ini berdampak pada saat setoran individu, ada santri yang tidak sempat setoran karena kehabisan waktu. Untuk mengatasinya ustadz-ustadzah memberlakukan sistem maju dua-dua. Ketika yang satu disemak, santri lain nderes kemudian membaca secara acak sesuai arahan ustad/ustadzahnya. Media papan peraga yang digunakan ukurannya kurang besar, dengan santri yang begitu banyak, santri yang duduk di belakang atau di samping kadang tidak begitu jelas melihat tulisan yang ada di papan peraga. Tes kenaikan kelas jilid/juz ditentukan oleh kepala Madrasah sebagai pentashih utama. Hal ini bertujuan untuk menjaga bacaan dan hafalan santri agar jelas gurunya (sanadnya) dan benar-benar sesuai dengan yang diharapkan dari penerapan metode yanbu'a.

Dengan penerapan metode yanbu'a yang sesuai langkah-langkah yang benar maka besar harapan santri dapat menjadi santri yang unggul, mampu membaca al-quran dengan lancar, cepat, tepat, dan benar, bahkan menjadi 


\section{Mohammad Rofiq dan Muhammad Abdul Basyid}

rangsangan bagi santri untuk menjadi penghafal al-quran. sebelum memakai metode Yanbu'a di MI Baitul Huda ini sudah memakai metode lain yaitu Qirati yang dirasa kurang cocok sehingga kepala Madrasah mengambil kebijakan untuk diganti menggunakan Yanbu'a.

Kelas enam menggunakan metode sorogan karena jam mengaji berbeda dengan kelas I-V, jam mengaji kelas I-V pagi hari sedangkan kelas VI siang hari. Masing-masing siswa kelas VI berbeda tingkat jilid Yanbu'anya, maka anak-anak maju satu persatu untuk membaca Yanbu'a di depan pembimbing, pembimbing akan menyimak dan membetulkan cara bacaan yang salah. Anak-anak tidak akan naik atau lanjut halamannya sampai benar-benar fasih. Untuk kenaikan jilid Yanbu'a, anak-anak akan dites oleh kepala Madrasah, yang mana beliau sudah hafidz dan fasih.

Dari hasil beberapa wawancara dapat saya simpulkan bahwa penerapan metode Yanbu'a di MI Baitul Huda untuk kelas VI waktu pelaksanaan pembelajaran berbeda dengan kelas I-V dimana, kelas I-V jam 07.00 WIB sedangkan untuk kelas VI jam 11.00 WIB. Sebab untuk kelas VI jam pagi digunakan untuk Les untuk menghadapi ujian yang akan dating.

Dari hasil beberapa wawancara untuk penerapan metode Yanbu'a di MI Baitul Huda dalam pelaksanaannya banyak menggunakan metode sorogan dan klasikal. Dari penjabaran diatas peneliti mempunyai beberapa kesimpulan terkait penerapan metode Yanbu'a di MI Baitul Huda yaitu: Pelaksanaan pembelajaran Alqur'an di MI Baitul Huda dimulai pukul 07.00-07.30 WIB untuk kelas I-V sedangkan untuk kelas VI dilaksanakan pada jam 11.00-11.30 WIB. Pelaksanaan pembelajaran Al-qur'an di MI Baitul Huda menggunakan metode klasikal dan sorogan. Anak-anak memiliki buku prestasi masing-masing sebagai catatan setiap mengaji. Kenaikan jilid dilakukan tes lagi dimana tes dilakukan dengan kepala Madrasah sebagai penguji. setiap hari sabtu jam 11.00 WIB semua Ustadz/ustadzah ngaji bareng dengan dibimbing oleh kepala madrasah.

\section{Peran Metode Yanbu'a dalam pembelajaran Al-Quran di MI Baitul Huda Semarang 2019/ 2020}


Metode yanbu'a dalam pembelajaran Alqur'an di MI Baitul Huda sangat membantu peserta didik dalam menguasai atau penguasaan ilmu Al-qur'an baik penulisan, bacaan Al-qur'anya sehinnga bisa membaca dengan lancar, benar dan fasih sesuai dengan kaidah ilmu tajwid. Hanya saja memerlukan proses yang cukup panjang untuk mencapai tujuan tersebut.

Disini peran guru juga sangat penting diantaranya adalah kesabaran yang perlu ditingkatkan dalam membimbing anak didik sehingga bisa mencapai tujuan yang diharapkan".

Dari beberapa hasil wawancara diatas peneliti bisa mengambil kesimpulan untuk penerapan metode Yanbu'a di MI Baitul Huda sebagai berikut: Metode yanbu'a sangat efektif untuk membelajaran Al-qur'an di MI Baitul Huda. Metode yanbu'a membantu siswa dalam hal kemampuan membaca Al-qur'an dengan lancar dan tartil sesuai dengan makharijul huruf dan kaidah-kaidah tajwid. Metode yanbu'a membantu kemampuan peseta didik atau santri menulis huruf Al-qur'an dan angka arab dengan Rosman Usmani. Metode yanbu'a membantu anak mempelajari dan membaca Al-quran sesuai dengan tajwid dan makhrajnya. Metode yanbu'a merupakan salah satu metode pengajaran al-quran yang menawarkan pembelajaran seefektif mungkin agar para santri tidak hanya dapat mampu membaca al-quran dengan baik, akan tetapi juga lancar (tartil), cepat, tepat (sesuai kaidah hukumnya), dan benar (sesuai makharijul hurufnya), atau yang sering disebut dengan LCTB (lancar, cepat, tepat, dan benar). Usia santri yang beragam mulai 7 tahun hingga usia 13 membuat kepala Madrasah dan dewan asatidz mantap memilih yanbu'a sebagai metode pengajaran al-qurannya. Selain santri akan mampu membaca al-quran dengan lancar, cepat, tepat, dan benar, yanbu'a mampu mewadahi keberagaman usia santri dengan bahan ajar dan media pengajaran yang lengkap.

Sarana prasarana pendukung penerapan metode yanbu'a di MI Baitul Huda juga sudah lengkap, mulai dari buku jilid pemula hingga jilid VII, kartu prestasi, buku materi hafalan, papan peraga, papan tulis, ruang kelas yang luas, hingga al- 
qur'an rosm Utsmani yang sejalan dengan prinsip yanbu'a. Semua tersedia lengkap untuk menunjang belajar santri

Ustadz-ustadzah yang telah mendapatkan ijazah yanbu'a menjadikan penerapan metode ini tidaklah sulit. Dengan modal yang telah dimiliki, akhirnya para ustadz-ustadzah bersinergi menerapkan metode yanbu'a dalam pembelajaran al-quran. Dengan dukungan alat belajar yang lengkap serta pengadministrasian yang baik para ustadz-ustadzah siap menjalankan amanah Yanbu'a.

Para ustadz/ustadzah siap mengatasi hambatan-hambatan yang terjadi. Jika ada guru yang tidak masuk maka ada guru yang bertugas sebagai badal atau pengganti guru yang tidak masuk. Faktor lain menghambat penerapan metode yanbu'a dalam pengajaran al-quran pun telah mendapatkan solusi. Santri yang tidak masuk lebih dari dua hari, ia akan mendapat bimbingan khusus dari ustadz pengajarnya. Bagi kelas yang santrinya cukup banyak, maka akan diajar oleh 2 ustadz. Lembaga juga menjalin hubungan yang baik dengan wali santri, karena berhasil atau tidaknya kegiatan belajar al-quran yang dijalani santri juga didukung oleh peran besar orang tua.

Dengan diketahuinya faktor penunjang dan penghambat ini dalam penerapan metode yanbu'a, maka dapat dijadikan masukan yang berarti bagi MI Baitul Huda untuk memperbaiki diri dan tetap fokus dengan tujuan utamanya yakni meningkatkan kualitas membaca al-quran para peserta didiknya.

\section{Simpulan}

Penerapan metode Yanbu'a dalam pembelajaran al-quran di MI Baitul Huda Semarang meliputi beberapa tahapan atau langkah, pertama perencanaan, yaitu semua ustadz/dzah menyiapkan bahan ajar yang akan digunakan dalam pembelajaran Al-qur'an seperti mengecek jilid, jurnal santri dan lain-lain, kemudian yang kedua adalah pelaksanaan, Dalam pelaksanaannya pembelajaran Alqur'an di MI Baitul Huda dilaksanakan pada pukul 07.00-07:30 WIB dengan menggunakan metode klasikal dan sorogan. Kemudian yang ketiga evaluasi, dimana ada buku jurnal sebagai catatan hasil mengaji masing-masing anak, buku 
jurnal tersebut sebagai raport hasil mengaji setiap harinya apakah siswa tersebut naik halaman atau mengulang, kemudian dalam kenaikan jilid para santri harus melakukan tes lagi dengan kepala madrasah. Dalam pelaksanaan pembelajaran AlQur'an ustadz-ustadzah tidak mengalami kesulitan yang berarti karena metode ini mudah diterapkan. Terdapat banyak petunjuk bagaimana penerapan metode ini di kelas, khususnya dalam pembelajaran al-quran. Peran metode yanbu'a dalam pembelajaran Al-Qur'an di MI Baitul Huda yang pertama membantu siswa/santri dalam kemampuan membaca Al-quran dengan bacaan tartil sesuai dengan makharijul huruf dan kaidah-kaidah tajwid, selain itu juga membantu kemampuan menulis huruf Al-quran dan angka arab dengan Rosman Usmani. Yang kedua Metode yanbu'a dalam pembelajaran Al-quran di MI Baitul Huda sangat membantu siswa/santri dalam menguasai ilmu Al-quran baik penulisan, bacaan Al-quranya sehingga bisa membaca dengan lancar, benar dan fasih sesuai kaidah ilmu tajwid. Hanya saja memerlukan proses waktu yang cukup panjang untuk mencapai tujuan tersebut. Peran orangtua juga sangat penting dalam penanaman kecintaan Al-quran mulai dari masa kanak-kanak. Karena hal itu akan menjadi modal besar bagi dewasanya kelak dan menjadikan generasi Qur'ani.

\section{Daftar Pustaka}

Al-Qattan, M. K. (2001). Studi Ilmu-ilmu al-Qur'an. terj. Mudzakir AS, Jakarta.

Amalia, I. (2015). Pembelajaran Al-Qur'an dengan Metode Yanbu'a di PP. AsSa'idiyyah. http://indatulamalia.blogspot.co.id/2015/11/pembelajaran-al-qurandengan-metode

Arwani, U. albab. (2004). Thoriqoh Baca Tulis dan Menghafal Al-Qur'an Yanbu'a.

Best, J. W., Faisal, S., \& Waseso, M. G. (1982). Metodologi Penelitian Pendidikan. Usaha Nasional.

Dimyati, M. (2006). Belajar dan pembelajaran. Jakarta: Rineka Cipta.

Fatmawati, N. (2020). "Gaya Hidup Mahasiswa Akibat Adanya Online Shop". Jurnal Pendidikan Ilmu Sosial, 29 (1): 29-38.

Fatmawati, N., Setyowati, D. L., \& Utomo, C. B. (2018). "Outdoor Study Activity by 
Utilizing Wonosoco Tourism Village as A Learning Resource of Social Studies". Journal of Educational Social Studies, 7 (1): 88-98.

Kurniawan, D. (2014). Pembelajaran terpadu tematik (Teori, praktik, dan penilaian). Bandung: Alfabeta.

Lexy, J. M. (2002). Metodologi penelitian kualitatif. Bandung: Remaja Rosdakarya.

Majid, A. (2008). Perencanaan pembelajaran. Bandung: PT Remaja Rosdakarya.

Marianti, L. (2016). Dampak Globalisasi dalam pendidikan. Kompasiana.

Mufarokah, A. (2009). Strategi Belajar Mengajar. In Teras. Teras.

Rohmad, A. (2004). Kapita Selekta Pendidikan, Jakarta: PT. Bina Ilmu.

SAIFUDIN, I. (2017). STRATEGI PEMBELAJARAN YANG DITERAPKAN GURU PAI DALAM MENINGKATKAN KEMAMPUAN MEMBACA AL-QUR'AN SISWA MELALUI KEGIATAN DINIYAH DI SMPN 3 TUGU TRENGGALEK.

Sudjana, N. (2009). Penilaian hasil belajar proses belajar mengajar. Bandung: PT Remaja Rosdakarya.

Sugiono, S. (2013). Metode Penelitian Kualitatif. Bandung: Alfabeta.

Suharsimi, A. (2009). Dasar-dasar evaluasi pendidikan. Jakarta: Bumi Aksara.

Syah, M. (2006). Psikologi Belajar, Jakarta: PT. Raja Grafindo Persada. 